\title{
Mesjanizm w kwartalniku "Kronos” 2014, nr 2 (29), ss. 317
}

DOI: http://dx.doi.org/10.12775/RF.2014.022

Wydaje się, że czasach, kiedy postmoderniści głoszą ostateczny kres filozofii maksymalistycznych i systemowych oraz bezlitośnie demaskują złudność i szkodliwość wiary w „wielkie narracje”, słowo „mesjanizm” utraciło ostatecznie rację bytu w słowniku pojęć współczesnej kultury. W tym kontekście decyzja Redakcji kwartalnika „Kronos”, by poświęcić temu zjawisku kulturowemu osobny numer czasopisma, zakrawa wręcz na prowokację, choć z całą pewnością świadomą i zamierzona, bo - jak pisze Wawrzyniec Rymkiewicz w Edytorialu: „Inteligent polski uważa dzisiaj mesjanizm za powód do wstydu albo do śmiechu, za rodzaj lokalnego dziwactwa" (s. 3). Czy mamy więc do czynienia z całkowitym zmierzchem mesjanistycznych idei, które w przeszłości kształtowały naszą polską kulturę i mentalność, zwłaszcza w czasach zaborów? Choć od początku nowego tysiąclecia upłynęło już kilkanaście lat i zapowiadany koniec historii nie nastąpił, a zatem otwiera się przestrzeń dla kolejnych oczekiwań, to jednak ciągle jesteśmy podejrzliwi wobec tego typu propozycji, także z obawy przed możliwą powtórką uproszczonych i totalitarnych wizji, które $\mathrm{w}$ XX wieku przyniosły zagładę milionów niewinnych istnień ludzkich.

Redakcja i autorzy są świadomi złożoności tej problematyki i dlatego zaproponowali czytelnikowi rodzaj długiej podróży w przeszłość, poza czasy nowożytne, aby tam szukać inspiracji dla rozmaitych mesjanizmów, które w ciągu ostatnich kilku wieków kształtowały oblicze zachodniego świata. Tezą jaką stawia Redakcja „Kronosa”, jest przekonanie, że u źródeł zachodniego mesjanizmu znajdziemy postać Joachima z Fiore (1135-1202). Nie jest ona czymś nowym, ponieważ w XX wieku autorzy tacy jak Alois Dempf, Karl Löwith, Jacob Taubes, Oswald Spengler, Eugen Rosenstock-Huessy, Norman Cohn czy Eric Voegelin wyrażali przekonanie, że wiodące elementy Joachimowej spuścizny wyszły poza ich średniowieczny kontekst i ukształtowały europejską tradycję, również w jej nowożytnych przejawach. 
W przypadku Joachima z Fiore mamy do czynienia z myśleniem nie tylko religijnym, lecz także wyartykułowanym teologicznie i do tego stopnia nośnym ideowo, że mogło wystąpić w innych niż dwunastowieczny kontekstach. Warto przywołać w tym momencie główną tezę Karla Löwitha, zawartą w siódmym rozdziale jego Meaning of History z 1949 roku, znanej polskiemu czytelnikowi jako Historia powszechna i dzieje zbawienia. Teologiczne przesłanki filozofii dziejów:

Podobnie jak Luter po nim, i Joachim nie mógł przewidzieć, że jego religijny zamysł odświecczenia Kościoła wyrodzi się w rękach innych ludzi w swe przeciwieństwo: w sekularyzację świata, wspomaganą właśnie przez to, że myślenie eschatologiczne przetransponowano na rzeczy przedostatnie, wskutek czego wzmógł się impet świeckich ataków zmierzających do ostatecznego rozwiązania problemów, których nie sposób w ogóle rozwiązać ani uleczyć na ich własnej płaszczyźnie i za pomocą ich własnych środków ${ }^{1}$.

Jak łatwo zauważyć, jest to teza niezwykle złożona i pobudzająca do szerszej debaty nad obliczem nowożytności. By jednak do takiej merytorycznej wymiany zdań mogło dojść, należy się wcześniej zapoznać $\mathrm{z}$ istotą Joachimowego przesłania, a to nie zawsze jest łatwe.

Już od kilkudziesięciu lat trwają badania mediewistów skupionych wokół powstałego w latach osiemdziesiątych ubiegłego wieku Międzynarodowego Centrum badań nad Joachimem z Fiore (Centro Internazionale di Studi Gioachimiti) z siedzibą w kalabryjskim San Giovanni in Fiore. Obok zaawansowanych prac nad edycją opera omnia Joachima $\mathrm{z}$ Fiore ukazało się $\mathrm{w}$ tym czasie wiele cennych monografii, a także ogromna liczba artykułów, z których część stanowi pokłosie ośmiu kongresów o zasięgu światowym, poświęconych wybranym aspektom Joachimowej spuścizny. Polski czytelnik ma, jak dotychczas, do dyspozycji tylko jedną monografię poświęconą temu średniowiecznemu autorowi, a także szereg artykułów w czasopismach i monografiach zbiorowych, z których pierwsze zaczęły się ukazywać jako owoc badań wybitnych mediewistów, Tadeusza Manteuffla i Stanisława Byliny. Podjętą przez Instytut Filozofii Uniwersytetu Warszawskiego inicjatywę opublikowania wybranych tekstów Joachima z Fiore, przetłumaczonych na język polski, oraz komentarzy mediewistów należy więc uznać za jak najbardziej pożyteczną i służącą wspomnianej pogłębionej refleksji nad obliczem czasów nowożytnych.

Tematyka bezpośrednio lub pośrednio związana z Joachimem z Fiore została zaprezentowana $\mathrm{w}$ dwóch blokach tematycznych: Prezentacje (s. 5-140) i Eseje (s. 141-272). Otwierający Prezentacje artykuł Rafała

1 K. Löwith, Historia powszechna $i$ dzieje zbawienia. Teologiczne przesłanki filozofii dziejów, przeł. J. Marzęcki, Wydawnictwo Antyk, Kęty 2002, s. 153. 
Tichego, noszący tytuł Od hermeneutyki do historiozofii (s. 5-35), stanowi rodzaj koniecznego wstępu do Joachimowej egzegezy i osadzonej w niej wizji dziejów. Trudno zagłębić się w niełatwą lekturę profetycznej spuścizny, jaką pozostawił nam Joachim z Fiore, bez zapoznania się z egzegetycznym instrumentarium jego profetyzmu. Autor w ciekawy sposób prowadzi czytelnika poprzez dzieje biblijnej egzegezy ojców Kościoła i wczesnochrześcijańskich pisarzy, nie tracąc z oczu przemian zachodzących w obrębie tej ostatniej, np. stopniowego przechodzenia „od teologii historii i opartej na niej eschatologii ku teologii życia wewnętrznego i eschatologii indywidualnej" (s. 17) czy przemożnego wpływu św. Augustyna na początki chrześcijańskiej historiozofii. Na tym patrystycznym i wczesnośredniowiecznym tle "poaugustyńskiej hermeneutyki” (s. 20) jeszcze wyraźniej jawią się elementy Joachimowego novum, czyli Chrystus jako oś dziejów świata, tertius status lub epoka Ducha Świętego i zdwojenie eschatonu (s. 27), a co za tym idzie także dwie odsłony postaci Ostatecznego Przeciwnika, czyli Antychrysta. Autor zmierzył się również z rozbudowaną teorią sensów biblijnych, widoczną w dziełach Joachima z Fiore, a zwłaszcza w Księdze zgodności Starego i Nowego Testamentu i Psalterium o dziesięciu strunach.

Pewnym mankamentem tak ukazanej apokaliptyki Joachima z Fiore jest brak wzmianki o realiach historycznych XII wieku, które miały na nią wpływ. Kalabryjski opat jest świadkiem rosnącego w siłę islamu. Wystarczy wspomnieć, że początek podjętej przez niego reformy zakonu cysterskiego, której owocem są florensi, przypada na czas militarnych sukcesów Saladyna i upadku Jerozolimy, których konsekwencją była kolejna krucjata. Jako osoba bliska środowisku kurii rzymskiej, a zatem dobrze poinformowana, Joachim zdaje sobie również sprawę z zagrożenia, jakie niosą ze sobą ówczesne herezje, zdobywające zwolenników na terenie dwunastowiecznego świata chrześcijańskiego. Te dwa budzące grozę zjawiska jawią się $w$ jego apokaliptyce jako dwie bestie z Janowej Apokalipsy (Ap 13) i zapowiedź bliskiego końca świata, a ciekawym ikonograficznym nawiązaniem do nich są dwie głowy Smoka wyrastające z jednej szyi, widoczne w Liber Figurarum. Sytuacja, w której w łonie zachodniego świata dochodzi do gorszących podziałów i to $\mathrm{w}$ momencie, gdy wrogowie chrześcijaństwa zwierają szyki, jest dla Joachima wyraźną zapowiedzią bliskiego końca świata².

2 Warto w tym miejscu wspomnieć o interesującym szczególe, jaki pojawia się w Joachimowym komentarzu Apokalipsy. Komentując wizję szóstego anioła (Ap 9,13-17), opat przywołuje zasłyszaną w 1195 roku w sycylijskiej Mesynie pogłoskę o wysłaniu przez zachodnich heretyków poselstwa do władców muzułmańskich z propozycją zawarcia z nimi przymierza - zob.: Expositio magni prophete Abbatis Ioachim in Apocalipsim, Venetiis 1527, f. 134b; J. Grzeszczak, Joachim z Fiore. Średniowieczny przyczynek do teologii dziejów, Studia i Materiały - Uniwersytet im. Adama Mickie- 
„Kronos” po raz pierwszy daje czytelnikowi możliwość zapoznania się z tłumaczeniami na język polski wybranych fragmentów dzieł Joachima z Fiore, co należy docenić i uznać za inicjatywę bardzo pożądaną. Wybrane przez Redakcję dzieła są reprezentatywne dla spuścizny tego średniowiecznego autora, a zawarta w nich problematyka oscyluje wokół jego hermeneutyki tekstów biblijnych i apokaliptycznej wizji dziejów. Czytelnik ma okazję zapoznać się z sześcioma fragmentami Księgi zgodności Starego i Nowego Testamentu, całością niewielkiego dzieła Wprowadzenie do Apokalipsy, fragmentem Liber introductorius in Apocalypsim z weneckiego wydania Joachimowego obszernego komentarza Apokalipsy, fragmentów Psalterium o dziesięciu strunach, traktatem O siedmiu pieczęciach, Listem do wielebnego opata z Valdony oraz Listem do wszystkich wiernych. Całość tłumaczonych tekstów dopełnia Przepowiednia znaleziona przez brata Gerarda z zakonu braci mniejszych, będąca przykładem trzynastowiecznej recepcji Joachima z Fiore $w$ kręgach franciszkańskich.

Polski przekład artykułu Bernarda McGinna, Symbolism in the Thought of Joachim of Fiore (s. 88-104), jest dla czytelnika okazją do zapoznania się z wynikami badań światowej klasy mediewistów, zajmujących się problematyką średniowiecznego profetyzmu. Praca tego amerykańskiego badacza, znanego polskiemu czytelnikowi głównie z opracowań poświęconych historii chrześcijańskiej duchowości i mistyki, ukazała się w 1980 roku w bogatej w cenne teksty na temat Joachima z Fiore i joachimizmu księdze pamiątkowej, dedykowanej Marjorie Reeves (1905-2003)3․ To właśnie jej wieloletnie badania nad Joachimem z Fiore przyczyniły się do ukazania roli, jaką odegrał w europejskiej kulturze. Wystarczy przypomnieć w tym miejscu wydaną po raz pierwszy w 1969 roku fundamentalną pracę tej oksfordzkiej mediewistki, The Influence of Prophecy in the Later Middle Ages. A Study in Joachimism ${ }^{4}$.

Matthias Riedl zajął się w swojej udostępnionej teraz w języku polskim pracy jednym z najbardziej tajemniczych aspektów spuścizny kalabryjskiego opata, czyli społeczeństwem przyszłości (s. 105-121). Już w średniowieczu szukano dróg łatwiejszego dostępu do jego intrygującej wizji dziejów i owocem tych poszukiwań jest Liber Figurarum, czyli zbiór kilkunastu diagramów w formie często bogato iluminowanych tablic, będących graficzną syntezą wiodących elementów Joachimowej myśli. Sam opat z Fiore korzystał z możliwości, jaką stwarzał obraz, co

wicza w Poznaniu. Wydział Teologiczny, t. 87, Uniwersytet im. Adama Mickiewicza. Wydział Teologiczny. Redakcja Wydawnictw, Poznań 2006, s. 148.

3 Zob. B. McGinn, Symbolism in the Thought of Joachim of Fiore, w: Prophecy and Millenarianism. Essays in Honour of Marjorie Reeves, red. A. Williams, Longman, Harlow 1980, s. 143-164.

4 Zob. M. Reeves, The Influence of Prophecy in the Later Middle Ages. A Study in Joachimism, University of Notre Dame Press, Notre Dame-London $1993^{2}$. 
przyczyniło się do powstania późniejszej legendy, jakoby był utalentowanym artysta, a nawet projektodawcą cyklu mozaik w weneckiej bazylice św. Marka. Tablica ukazująca wzorowany na niebiańskim Jeruzalem projekt społeczeństwa w epoce Ducha Świętego (Dispositio novi ordinis pertinens ad tertium statum ad instar supernae Jerusalem) ukazuje w szczegółach teologiczny projekt organizacji życia wspólnoty, której celem jest kontemplacja. $Z$ jednej strony zamiar taki nie był czymś zupełnie nowym w dziejach zachodniej cywilizacji, z drugiej jednak - jak słusznie zauważa Matthias Riedl - „w strukturalnej zasadzie konstytucji czuć ducha nowoczesności" (s. 121). W tym kontekście ciekawym zagadnieniem badawczym pozostaje problem prób przełożenia mentalności eschatologicznej, widocznej u franciszkańskich joachimitów, na utopijne wizje organizacji życia wspólnot, zasiedlających u progu czasów nowożytnych dopiero co odkryte obszary Nowego Świata 5 .

Zamykający dział Prezentacje artykuł Jana Grzeszczaka, Głos teologa w sprawach średniowiecznej polityki. Diagramy Roma i Babilonia oraz ich wymowa doktrynalna i moralna (s. 122-140), pozostaje w kręgu Liber Figurarum i ukazuje Joachimowe rozumienie dziejowych procesów w dialektyce upadku i powstawania z niego. Konkretny jej przykład znaleźć można w niewielkim objętościowo traktacie Joachima z Fiore, Intelligentia super calathis ad abbatem Gafridum, którego edycja krytyczna ukazała się ostatnio jako owoc współpracy pomiędzy Istituto Storico Italiano per il Medio Evo i Centro Internazionale di Studi Gioachimiti ${ }^{6}$.

Zapoznając się z działem Eseje, czytelnik „Kronosa” ma możliwość kontynuowania podróży śladami Joachima z Fiore w europejskiej kulturze. "Skandal Wieczystej Ewangelii” w wydaniu franciszkańskiego radykalnego joachimity, Gerarda z Borgo San Donnino, pozostawił trwały ślad w późnośredniowiecznym i nowożytnym piśmiennictwie. Dopiero jednak w XIX wieku przychodzi pora na autentyczny przełom w badaniach nad samym Joachimem i jego spuścizną7. W latach pięćdziesią-

5 Zob.: S. Castellanos de García, Concretización de la ciudad los Angeles: su traza y paralelismo con la Jerusalén Celeste, su escudo. Reflejo del Joaquinismo-Franciscano y del apocalipticismo romano renacentista, „Florensia. Bollettino del Centro Internazionale di Studi Gioachimiti" 1999-2000, nr 13/14, s. 45-96; L.A. García Lastra, Joaquinismo, profecía y apocalipticismo. La Utopía Angelopolitana, Jerusalén Celeste de la Nueva Espa$\tilde{n} a$, „Florensia. Bollettino del Centro Internazionale di Studi Gioachimiti” 1999-2000, nr 13/14, s. 105-137.

6 Zob. Joachim abbas Florensis, Intelligentia super calathis ad abbatem Gafridum, w: idem, Scripta breviora, red. A. Patschovsky, G.L. Potestà, Fonti per la Storia dell'Italia medievale, Antiquitates, t. 40, L'Istituto Storico Italiano per il Medio Evo, Roma 2014, s. $183-218$.

7 Na temat „Wieczystej Ewangelii” w europejskim piśmiennictwie od XIII do XX wieku - zob.: M. Reeves, W. Gould, Joachim of Fiore and the Myth of the Eternal Evangel in the Nineteenth Century, Oxford University Press, Oxford 1987; J. Grzeszczak, Spór o "czasy i chwile" wczoraj i dziś, w: idem, Chwila jest bliska. Wizje końca w literaturze 
tych XIX wieku Ernest Renan, po okresie rozczytywania się w Spiridionie George Sand, gdzie obwieszczona przez Joachima z Fiore epoka Ducha Świętego poddana została daleko idącym reinterpretacjom $\mathrm{w}$ duchu rewolucji francuskiej, przystąpił do studiów nad średniowiecznymi rękopisami w paryskiej Bibliotece Narodowej i opublikował w 1866 roku oparty na źródłach artykuł Joachim de Flore et l'Évangile éternel ${ }^{8}$. Przedruk tego dzieła, opublikowany kilkanaście lat później, został obecnie udostępniony polskiemu czytelnikowi w tłumaczeniu Piotra Napiwodzkiego (s. 141-182).

Z właściwą sobie swadą i zmysłem krytycznym Renan analizuje fenomen Joachima z Fiore, odróżniając autentyczne teksty tego ostatniego od przypisywanych mu przepowiedni i trzynastowiecznych traktatów profetycznych. Warto w tym kontekście przywołać wyodrębnione przez niego kryteria rozpoznawania autora tekstów, świadczące o pogłębionej znajomości problematyki. Francuski historyk pisze:

Gdy Joachim chce być prorokiem, czyni to dyskretnie i z rezerwą. Nie wymienia żadnej osoby, wydarzenia są ledwo zarysowane, częste odwołania do stylu biblijnego owocują zdaniami niejasnymi, które stają się prorockimi zapowiedziami, gdy przychodzą odpowiadające im wydarzenia, a przy tym nie dyskredytują się, gdy wydarzenia idą w innym kierunku (s. 147).

Renan pozytywista nie omieszkał też zabrać głosu na temat mesjanizmu i ewentualnego wpływu wizji Joachima na ukształtowanie się nowożytności. Podsumowując swoje rozważania na temat późnośredniowiecznej spuścizny opata z Fiore, Renan stwierdza:

Oburza nas okrucieństwo środków użytych dla unicestwienia tych dziwnych nauk i potępienie wielu chwalebnych aspiracji; można jednak powiedzieć, że prawdziwy postęp nie dokonał się dzięki tym dobrodusznym członkom sekt. Postęp dokonywał się $\mathrm{w}$ równoległym ruchu niosącym ludzki umysł ku nauce, ku reformom politycznym, ku ostatecznemu ukonstytuowaniu się społeczeństwa świeckiego. Od roku 1255 można już uznać, że postęp, w rozumieniu nowożytnym, nadchodził z góry, nie z dołu, ze strony rozumu, nie wyobraźni, od zdrowego rozsądku, nie od entuzjazmu, od ludzi racjonalnych, nie od wizjonerów szukających tajemnic przeznaczenia w urojonych porównaniach (s. 182).

profetycznej (XII-XX wiek), Biblioteka Filozofii Chrześcijańskiej, t. 3, Uniwersytet im. Adama Mickiewicza. Wydział Teologiczny. Redakcja Wydawnictw, Poznań 2011, s. 154-159.

8 Zob. E. Renan, Joachim de Flore et l'Évangile éternel, „Revue des deux mondes” 1866, nr 64, s. 94-142. 
Trudno nie zauważyć, że w tej próbie całościowej oceny joachimizmu, Renan pozytywista ostatecznie przeobraża się w Renana sceptyka.

Piotr Napiwodzki, tłumacz na język polski wspomnianego tekstu Renana, nie zniechęca się wyciągniętymi przez francuskiego historyka wnioskami i w swoim artykule, Nowożytność jako tryumf joachimizmu (s. 183-192), podejmuje się - jak sam twierdzi - „dosyć karkołomnego zadania", polegającego na odwróceniu perspektywy i spojrzeniu na całą nowożytność jako na czas zwycięstwa idei zapowiadanych przez Joachima i jego uczniów (s. 185). Odnosi się wrażenie, że rozważając charakterystyczną dla późnego średniowiecza konfrontację idei (spór pomiędzy tomistyczną scholastyką i woluntaryzmem Wilhelma Ockhama), zachodzące wówczas wewnątrzkościelne procesy czy rolę myślenia utopijnego u progu nowożytności, autor jest bardziej skoncentrowany na stawianiu pytań niż dawaniu odpowiedzi. Nic w tym dziwnego, jeśli weźmiemy pod uwagę ciężar gatunkowy poruszanych zagadnień, wśród których na plan pierwszy wysuwa się problem sekularyzacji.

Tekst Ernsta Blocha z jego Das Prinzip Hoffnung, zatytułowany Joachim z Fiore, trzecia Ewangelia i jej królestwo, przenosi czytelnika w krąg komunistycznej ideologii jako utopii społecznej (s. 193-198). Jak słusznie zauważa Ernst Bloch, widoczne u Joachima z Fiore „umiejscowienie Królestwa Światłości nie w zaświatach, w roli transcendentnej pociechy, lecz w historii" (s. 194) w pewnym stopniu zbliża myśl tego średniowiecznego autora do marksistowskich rozwiązań, widocznych w Manifeście komunistycznym, choć nie należy zapominać, że teologiczny horyzont opata z Fiore ani na moment nie pozwała mu ulec pokusie redukcji jego oczekiwań do wymiarów doczesnych. Tezy Ernsta Blocha, wyrażone w Das Prinzip Hoffnung, spotkały się z odpowiedzią ze strony przedstawicieli środowisk chrześcijańskich, czego wyrazem była m.in. dyskusja, jaką w latach sześćdziesiątych ubiegłego wieku podjął z nim protestancki teolog, Jürgen Moltmann?.

W kręgu komunistycznej utopii pozostaje niewielki objętościowo artykuł Piotra Graczyka, Ernst Bloch $i$ dwa mity antropogenezy (s. 199-202). Po jego lekturze trudno oprzeć się smutnej refleksji, że autentyczny sens chrześcijaństwa został sprowadzony przez Blocha do diabolicznego zdementowania Dobrej Nowiny:

Nie chodzi zatem o to, aby przezwyciężyć winę, ale żeby żyć w świecie, w którym nie ma winy, żyć w raju - co znaczy: wciąż łamać prawo i dlatego właśnie nigdy nie grzeszyć. Nie o to chodzi, by Boży posłaniec, Słowo Boże - Jezus Chrystus - nas zbawił, aby nas wyciagnął za uszy

9 Zob. J. Grzeszczak, Dall'Età dello Spirito Santo al New Age. Gioacchino da Fiore nella nuova religiosità, Wydawnictwo Rys, Poznań 2008, s. 214-217. 
z bagna faktów, ale o to, żebyśmy żyli w społeczności, w której wszyscy są jak Jezus - a mianowicie bezgrzeszni (s. 201).

Artykuł Pawła Grada, W imię Ojca. Tomistyczna krytyka joachimizmu (s. 203-213), po raz kolejny przenosi czytelnika w XIII wiek. Autor podejmuje dwa zagadnienia, będące przedmiotem krytyki ze strony św. Tomasza z Akwinu: teologię trynitarną Joachima z Fiore oraz jego historiozofię. Szukając źródeł, w których Joachim podejmuje polemikę wymierzoną w Piotra Lombarda, nie jesteśmy jednak zdani - jak twierdzi Paweł Grad - tylko na streszczenie poglądów opata z Fiore, zawarte w konstytucji Damnamus Soboru Laterańskiego IV (s. 206). Wymieniony w niej libellus sive tractatus, którego zawartość została potępiona przez ojców soborowych, to zaginione dzieło Joachima, De unitate seu essentia Trinitatis, choć trudno dzisiaj jednoznacznie rozstrzygnąć, czym tak naprawdę był ten traktat, w którym Joachim zwrócił się przeciwko Piotrowi Lombardowi ${ }^{10}$. Mamy jednak wgląd do autentycznych i zachowanych do dnia dzisiejszego dzieł opata z Fiore, na podstawie których można wyodrębnić rozbieżności pomiędzy Joachimem i Lombardem. Skierowany bezpośrednio pod adresem tego ostatniego zarzut "czwórcy" pojawia się w Joachimowym Tractatus in expositionem vite et regule beati Benedicti, gdzie Lombard występuje obok Sabeliusza i Ariusza, czyli starożytnych heretyków, którzy pobłądzili w nauce o Trójcy Świętej ${ }^{11}$. $\mathrm{W}$ innych dziełach opata Piotr Lombard nie zostaje wymieniony z imienia, lecz pojawiają się za to bardziej konkretne zarzuty pod adresem tych, którzy usiłują - zdaniem Joachima - bluźnierczo wprowadzać do Trójcy Świętej „,czwarty element”"12.

10 Większość badaczy, powołując się na dokumenty soborowe oraz zachowany katalog papieskiej biblioteki w Awinionie, twierdzi, że De unitate seu essentia Trinitatis faktycznie istniało i najprawdopodobniej powstało jako młodzieńcze dzieło opata z Fiore - zob. B. McGinn, L'abate calabrese. Gioacchino da Fiore nella storia del pensiero occidentale, przeł. P. i E. Di Giulio, Opere di Gioacchino da Fiore: strumenti, t. 2, Marietti, Genova 1990, s. 54-55, 182.

11 Rozważając wymowę oficjum recytowanego przez mnichów w różnych okresach roku liturgicznego, Joachim umieszcza je w kontekście zbliżającej się apokalipsy, która oznaczać będzie również oczyszczenie Kościoła z błędnych doktryn, podobnie jak miało to miejsce w przeszłości: „,abolita primo impietate Sabelli, qui personas negavit, secundo pravitate Arrii, qui unitatem scindit, tertio blasphemia Petri, qui unitatem a Trinitate dividens quaternitatem inducit". Ioachim abbas Florensis, Tractatus in expositionem vite et regule beati Benedicti cum appendice fragmenti (I) de duobus prophetis in novissimis diebus praedicaturis, red. A. Patschovsky, Fonti per la Storia dell'Italia medievale, Antiquitates, t. 29, L'Istituto Storico Italiano per il Medio Evo, Roma 2008, s. 208-209.

12 "Qui sic accipiunt unum, quod trium essentiam personarum, ut aliquod unum distinctum et proprium esse dicant; sic, inquam, aliquod unum singulare, quomodo cum credimus: Deus Pater unus est, Deus Filius unus est, Deus Spiritus Sanctus unus est, quasi quartum aliquid sit divina substantia. Ydolum adorant non Deum, quum 
Paweł Grad rozważa historiozofię w łączności z teologią Trójcy Świętej i to właśnie na tym tle dostrzec można różnice pomiędzy Joachimem i Akwinatą. Święty Tomasz jako wyraziciel tradycji jest też konsekwentnym zwolennikiem Augustyńskiego „schładzania” wszelkich dążeń o charakterze millenarystycznym. Jak pisze autor:

w perspektywie tomistycznej spodziewanie się dalszego postępu w historii po otrzymaniu nowego prawa Ewangelii, które jest doskonałym prawem, może oznaczać już tylko spodziewanie się historycznej realizacji usunięcia prawa, co sprzeciwia się tomistycznej ontologii rzeczywistości doczesnej. Usunięcie to oznaczałoby bowiem wejście na etap visio, przez które definiuje się (a zatem zostaje wyróżniony) stan chwały niebieskiej. Prawo - figura tradycji - pozostaje dla Tomasza obowiązująca formą uczestnictwa w życiu Trójcy i tajemnicy Ojca tak długo, jak długo trwa historia (s. 211).

Rozważana w konkluzji artykułu złożona koegzystencja dwóch ujęć, Joachimickiego i Tomaszowego, w kontekście sporu o nowożytność otwiera pole do szerokiej debaty. Już w połowie ubiegłego wieku Beryl Smalley zauważyła, że to Arystoteles ponosi faktyczną odpowiedzialność za destrukcję Joachimowej metody ${ }^{13}$. Nowa metoda uprawiania teologii, wkraczająca na trzynastowieczne uniwersytety, oparta jest na argumentacji, a nie na królującej dotychczas egzegezie, co ostatecznie nie pozostaje bez wpływu na kształt prowadzonej wówczas refleksji ${ }^{14}$.

Pozostając w kręgu średniowiecza, czytelnik „Kronosa” ma okazję zapoznać się z klasyką współczesnej niemieckiej historiografii, którą reprezentuje Herbert Grundmann - znakomity mediewista i faktyczny "odkrywca" Joachima z Fiore w latach dwudziestych ubiegłego wieku15. Jego artykuł z 1951 roku, Sacerdotium - Regnum - Studium. Zur Wertung der Wissenschaft im 13. Jahrhundert, w przekładzie Piotra Napiwodzkiego (s. 214-226) trafia do polskiego czytelnika po wydanej kilka lat temu pra-

quidem quartum aliquid non recipit fides nostra, sed tantum tres personas". Expositio magni prophete Abbatis Ioachim in Apocalipsim, f. 34b. Graficzne wyobrażenie Joachimowego postrzegania teologii trynitarnej Piotra Lombarda znaleźć można również w drezdeńskim kodeksie Liber Figurarum (Dresden, Sächsische Landesbibliothek, ms. A 121, ff. 87r-96v) - zob.: B. McGinn, L'abate calabrese, s. 179-183; M. Rainini, Disegni dei tempi. Il "Liber Figurarum" e la teologia figurativa di Gioacchino da Fiore, Opere di Gioacchino da Fiore: testi e strumenti, t. 18, Viella, Roma 2006, s. 267.

13 "The real exploder of Joachim's method was Aristotle". B. Smalley, The Study of The Bible in The Middle Ages, University of Notre Dame Press, Notre Dame 1978, s. 292.

14 Zob. ibidem, s. 292-294; J. Grzeszczak, Spór o "czasy i chwile" wczoraj i dziś, s. 171.

15 Zob. H. Grundmann, Studien über Joachim von Floris, Beiträge zur Kulturgeschichte des Mittelalters und der Renaissance herausgegeben von Walter Goetz, t. 32, Springer Fachmedien Wiesbaden GmbH, Leipzig-Berlin 1927. 
cy Jacka Soszyńskiego na temat przemian światopoglądowych, widocznych w średniowiecznych warstwach wykształconych ${ }^{16}$. Idea, w myśl której na trzech obszarach średniowiecznej Europy, zamieszkanych przez obdarzone specyficzną misją narody, koncentrują się trzy elementy stanowiące o całokształcie ówczesnej cywilizacji na tym kontynencie, ma posmak mesjanizmu, ideologii ważnej - jak twierdzi Grundmann „dla zrozumienia politycznych i intelektualnych przemian na drodze od średniowiecza do epoki nowożytnej" (s. 226).

Uwieńczeniem Joachimowej problematyki zawartej w "Kronosie” jest polskie tłumaczenie fragmentu obszernej dwutomowej monografii La posterité spirituelle de Joachim de Flore, w której wybitny francuski teolog, Henri de Lubac SJ (1896-1991), dokonał całościowego przeglądu europejskich idei nawiązujących do schematu dziejów, widocznego u opata z Fiore (s. 227-246) ${ }^{17}$. Przywołany wyżej fragment, noszący tytuł Kopuła Świętego Piotra, pochodzi z tomu drugiego i przenosi czytelnika w świat Wielkiej Emigracji, do Paryża lat czterdziestych XIX wieku. Adam Mickiewicz prowadził w tym czasie w Collège de France słynny cykl wykładów na temat literatur słowiańskich, które Henri de Lubac z właściwą sobie swadą analizuje pod kątem obecności w nich elementów nawiązujących do myśli kalabryjskiego opata.

Warto w tym miejscu przywołać krótki fragment dzieła francuskiego jezuity, w którym pojawia się streszczenie wykładu, jaki Mickiewicz zaprezentował 16 stycznia 1844 roku:

Noc Bożego Narodzenia. W Bazylice św. Piotra w Rzymie papież w otoczeniu zmęczonych starców kończy odprawiać mszę. Wśród nich pojawia się młodzieniec ubrany w purpurę - to Kościół przyszłości w osobie Jana. Ogłasza on zgromadzonym pielgrzymom, że czas się wypełnił; następnie podchodzi do grobu przywódcy apostołów, wzywa go po imieniu i nakazuje mu powstać. Ciało podnosi się i krzyczy: „Biada!”. Wtedy sklepienie kopuły bazyliki zaczyna pękać, pokrywając się rysami. Młody kardynał pyta: „Piotrze, czy poznajesz mnie?”. Ciało odpowiada: „Głowa twoja ostatniej wieczerzy spoczęła na piersi Pańskiej i tyś nigdy nie umarł na ziemi”. Jan na to: „A teraz kazano mi, bym wśród ludzi zamieszkał i ogarnął świat, i przytulił go do piersi, jako Pan głowę moją ostatniego wieczora”. Piotr na to: „Czyń, jak ci kazano jest” - i zapada się na powrót do grobu. Sklepienie bazyliki otwiera się, a Jan wznosi ręce, by ochronić uciekający lud; po raz pierwszy czyni rozkazujący gest, którym zatrzymuje Piotra w grobie, i pyta legion polskich pielgrzymów, czy chcą pozostać i dać się pogrzebać z najstarszym ze starców. Odpowiadają: „Sa-

16 Zob. J. Soszyński, Sacerdotium - Imperium - Studium. Władze uniwersalne w późnośredniowiecznych kronikach martyniańskich, Oficyna Wydawnicza ASPRA-JR, Warszawa 2006.

17 Zob. H. de Lubac, La posterité spirituelle de Joachim de Flore, Lethielleux, Collection Le Sycomore, t. 1, Paris 1979; t. 2, Paris 1981. 
memu gorzko jest umierać - a kto z nim umrze, jeśli nie my? [...] my nie umiemy uciekać!”. Po czym wznosząc swe szable, starają się powstrzymać walące się sklepienia, lecz jeden po drugim są przygniatani (s. 236).

Jak wiadomo, Mickiewicz zapożyczył tę legendę od innego wieszcza, Zygmunta Krasińskiego ${ }^{18}$. Występujący w niej dwaj Apostołowie, spoczywający w grobie Piotr i młodzieńczy Jan, są postaciami pojawiającymi się również w apokaliptyce Joachima z Fiore. W jego Księdze zgodności Starego i Nowego Testamentu papież w otoczeniu zmęczonych starców z Mickiewiczowskiej wizji wydaje się mieć swoich odpowiedników w biskupach Rzymu, którzy u schyłku epoki Syna przestaną zapładniać duchowo Kościół. Ich starotestamentowym typem jest - według Joachima - starość króla Dawida i obecność przy nim pięknej Szunamitki, Abiszag, która, „choć miała staranie o króla i obsługiwała go, król się do niej nie zbliżył" 19 . W napisanym u schyłku życia Traktacie o czterech Ewangeliach Joachim z Fiore dopatruje się w starcu Symeonie biskupów, którzy w momencie nadejścia nowej epoki dziejów radośnie i bez zazdrości wyśpiewają swoje Nunc dimittis i ustąpią miejsca oddanym kontemplacji mnichom ${ }^{20}$. Tę zmianę warty Joachim traktuje w kategoriach dziejowej konieczności: „Konieczne jest, by przeminęło to, co wyraża Piotr, a po-

18 Mowa o Legendzie z Trzech myśli pozostatych po śp. Henryku Ligenzie Zygmunta Krasińskiego. Wiktor Weintraub uważa to dzieło wieszcza za specyficznie polską wersję joachimizmu - zob.: Z. Krasiński, Trzy myśli pozostałe po śp. Henryku Ligenzie zmartym w Morreale 12 kwietnia 1840 roku, w: idem, Dzieła literackie, t. 2, Państwowy Instytut Wydawniczy, Warszawa 1973, s. 769-779; W. Weintraub, Dokoła "Legendy" Krasińskiego (Krasiński i Lamennais), w: Krasiński żywy. Ksiażka zbiorowa wydana staraniem Zwiazku Pisarzy Polskich na Obczyźnie, red. W. Günther, Wydawca B. Świderski, Londyn 1959, s. 179; K. Wróblewska, Joachimist vestiges in Polish Romantic Thinkers: Cieszkowski, Mickiewicz, Krasiński, w: Gioacchino da Fiore nella cultura contemporanea. Atti del $6^{\circ}$ Congresso internazionale di studi gioachimiti, San Giovanni in Fiore - 23-25 settembre 2004, red. G. L. Potestà, Opere di Gioacchino da Fiore: testi e strumenti, t. 17, Viella, Roma 2005, s. 79-82.

19 Zob. Divini vatis Abbatis Joachim liber concordie novi ac veteris Testamenti, Per Simonem de Luere, Venetiis 1519, f. 95c; 1 Krl 1,1-4.

20 Zob.: Gioacchino da Fiore, Trattati sui quattro Vangeli, przeł. L. Pellegrini, Opere di Gioacchino da Fiore: testi e strumenti, t. 11, Viella, Roma 1999, s. 70-72; Łk 2,29-32. Nie można wykluczyć, że w przypadku Joachima na tego typu ujęcia teologiczne miały również wpływ wydarzenia historyczne. U schyłku XII wieku przeszło dziewięćdziesięcioletni wówczas papież Celestyn III rozważał swoje ustąpienie z urzędu pod warunkiem, że na jego miejsce zostanie wybrany wyznaczony przez niego kandydat, którym był kardynał Jan od św. Pawła. Kolegium kardynalskie było jednak innego zdania i już w dniu śmierci papieża, 8 stycznia 1198 roku wybrało liczącego wówczas trzydzieści sześć lat Lotariusza z Segni, który przyjął imię Innocentego III. Młody papież szybko okazał się jednak człowiekiem w pełni świadomym swoich prerogatyw Następcy św. Piotra. 
zostało to, co wyraża Jan" ${ }^{21}$. Stwierdzenia te, czytane z niepokojem przez trzynastowiecznych kościelnych hierarchów i zestawione z treścią płomiennych wykładów Mickiewicza w Collège de France, prowokują nas do zadania zasadniczego w tym kontekście pytania o to, czy wieszcz zetknął się kiedykolwiek z twórczością Joachima z Fiore. Jest to w gruncie rzeczy pytanie o tezę de Lubaca, widoczną w jego dwutomowej La posterité spirituelle.

Marilena Amerise i Pietro Messa postanowili przyjrzeć się bliżej podejściu francuskiego jezuity do spuścizny Joachima z Fiore i zebrali wyniki swoich badań w tekście opublikowanym w 2005 roku w czasopiśmie "Florensia" 22 . Jedną z głównych tez ich artykułu jest głębokie przekonanie, że La posterité spirituelle stanowi idealną kontynuację refleksji zawartych w Exégèse médiévale, opublikowanej przez de Lubaca na początku lat sześćdziesiątych ubiegłego wieku ${ }^{23}$. W dziele tym francuski teolog poświęca Joachimowi z Fiore osobny rozdział, w którym poddaje analizie poszczególne elementy jego spuścizny, wychodząc od tezy, w myśl której duchowe rozumienie może pozbawić chrześcijańską nadzieję jej właściwej treści i zamienić ją w doczesną eschatologię noszącą cechy utopii ${ }^{24}$. Wnioski, jakie de Lubac wyciąga u kresu swojej długiej podróży poprzez Joachimową doktrynę, ukazują ambiwalencję tej ostatniej: „W swoim rozumowaniu Joachim naraził na szwank - nie mając, jak się wydaje, takiego zamiaru - pełną wystarczalność Jezusa Chrystusa"25. Opat zakłada bowiem istnienie w Nowym Testamencie rzeczywistości, które traktuje jako li t e r ę, zapowiedź tego, co ma dopiero nadejśćc ${ }^{6}$. Podobne do wyrażonego przez autora Exégèse médiévale stanowisko zajął Henri Mottu w swojej rozprawie z lat siedemdziesiątych ubiegłego wieku, poświęconej teologii późnego Joachima, widocznej w jego Traktacie o czterech Ewangeliach. Szwajcarski teolog stwierdza w niej, że dla opata z Fiore "cała Ewangelia zmierza do tego, by stać się czymś w rodzaju Protoewangelii Ewangelii Ducha Świętego" ${ }^{\prime 27}$. Reasumując, Henri de Lubac zauważa u Joachima dwa zasadnicze problemy: arbitralną meto-

${ }^{21}$ „Necesse est enim, ut transeat significatum Petri et maneat significatum Iohannis". Ioachimi abbatis Florensis Psalterium decem cordarum, red. K.-V. Selge, Monumenta Germaniae Historica, Quellen zur Geistesgechichte des Mittelalters, t. 20, Ioachimi Abbatis Florensis Opera Omnia, Hahnsche Buchhandlung, Hannover 2009, s. 244.

${ }_{22}$ Zob. M. Amerise, P. Messa, Gioacchino da Fiore e Henri de Lubac, „Florensia. Bollettino del Centro Internazionale di Studi Gioachimiti" 2004-2005, nr 18/19, s. 9-37.

${ }_{23}$ Zob. ibidem, s. 18; pierwsze wydanie w języku francuskim: H. de Lubac, Exégèse médiévale. Les quatre sens de l'Écriture, Gallimard, Paris 1961.

24 Zob. H. de Lubac, Esegesi medievale, przeł. P. Stàcul, t. 3, Jaca Book, Milano 1997, s. 585.

25 Ibidem, s. 750.

26 Zob. M. Amerise, P. Messa, Gioacchino da Fiore, s. 17.

27 ,tout $l^{\prime}$ Evangile tend à devenir quelque chose comme un Protoévangile de l'Evangile de l'Esprit". H. Mottu, La manifestation de l'Esprit selon Joachim de Fiore. Her- 
dę egzegezy i brak chrystocentrycznego zakorzenienia jego doktryny ${ }^{28}$. Warto w tym miejscu zaznaczyć, że już św. Tomasz z Akwinu, podążając w argumentacji za św. Augustynem, zdystansował się od Joachimowej metody egzegetycznej opartej na zgodności (concordia) Starego i Nowego Testamentu, twierdząc, że jakkolwiek ogólnie Nowe Przymierze znajduje swoją zapowiedź w Starym, to jednak nie należy się spodziewać, że ich poszczególne elementy będą sobie dokładnie odpowiadać, a kto sądzi inaczej, zdaje się na z gruntu omylne przewidywania ludzkiego umysłu ${ }^{29}$.

Chrystologia opata z Fiore ma znacznie dalej idące reperkusje. Joachim umieszcza w centrum swojej refleksji nad dziejami Trójcę Święta odsuwając na dalszy plan tradycyjną koncepcję chrystocentryczną. Konsekwencją tego typu rozwiązania jest przeniesienie w wymiar czasowy tego, czego dotychczas spodziewano się w wieczności. Jak łatwo zauważyć, przyjęcie tej opcji staje się pożywką dla wszelkiego rodzaju oczekiwań na "trzecie królestwo", które ma nadejść w ramach historii. Henri de Lubac jest tego świadom i w pierwszym tomie La posterité spirituelle pisze:

Historia duchowego dziedzictwa Joachima jest więc także, w większości przypadków, historią zdrady jego myśli. Tak się stało zaraz po jego śmierci. Nie popełnił jednak całkowitego błędu (może w niektórych przypadkach) ten, kto widział w nim prekursora i ojca chrzestnego wielu różnej maści szalonych marzeń, a także przedsięwzięć bardzo dalekich od tego, czego sam się spodziewał, i będących zdecydowanym zaprzeczeniem tego wszystkiego, co umiłował. Na każdym etapie rozwoju różnorodne

méneutique et théologie de l'histoire d'après le "Traité sur les Quatre Evangiles", Delachaux \& Niestlé, Neuchâtel-Paris 1977, s. 53.

28 Zob. M. Amerise, P. Messa, Gioacchino da Fiore, s. 23.

29 "quamvis status novi testamenti in generali sit praefiguratus per statum veteris testamenti; non tamen oportet quod singula respondeant singulis, precipue cum in Christo omnes figurae veteris testamenti fuerint completae; et ideo Augustinus, 18 de Civ. Dei, respondet quibusdam, qui volebant accipere numerum persecutionum quae Ecclesia passa est et passura secundum numerum plagarum Aegypti, dicens: »ego per illas res gestas in Aegypto istas persecutiones prophetice significatas esse non arbitror; quamvis ab eis qui hoc putant, exquisite et ingeniose illa singula his singulis comparata videantur, non prophetico spiritu, sed conjectura mentis humanae, quae aliquando ad verum pervenit, aliquando fallitur «. Et similiter videtur esse de dictis abbatis Joachim, qui per tales conjecturas de futuris aliqua vera praedixit, et in aliquibus deceptus fuit". Scriptum super Sententiis, lib. 4, dist. 43, q. 1, a. 3, w: http://www.corpusthomisticum.org/iopera.html [dostęp: 18.06.2015]; Sw. Augustyn, Państwo Boże, XVIII, LII, przeł. W. Kubicki, Wydawnictwo Antyk, Kęty 1998, s. 750. 
w swoich przejawach Joachimowe dziedzictwo mogłoby odwołać się do swojego początku, aby uprawomocnić jego kolejną zdradę ${ }^{30}$.

Wydaje się, że przytoczone stwierdzenia stały się dla francuskiego teologa swego rodzaju credo, które towarzyszyło mu w długiej podróży poprzez dzieje duchowego dziedzictwa opata z Fiore. W tej wędrówce, podjętej z przekonaniem, że jakikolwiek dyskurs na temat "trzeciego królestwa" zakorzeniony jest w Joachimowej wizji, Henri de Lubac zajrzał również do auli Collège de France, aby przez chwilę posłuchać głosu wielkiego przybysza z rozdartej przez zaborców Polski.

Pierre Teilhard de Chardin, myśliciel dzisiaj w znacznym stopniu przebrzmiały, jest tematem artykułu Marcina Karasa, który podejmuje próbę analizy jego „doczesnego mesjanizmu” (s. 247-256). Autor stwierdza we wprowadzeniu, że po fali fascynacji wizją francuskiego jezuity, badacze są dzisiaj w bardziej komfortowej sytuacji, również ze względu na znaczne nagromadzenie literatury na jego temat. W artykule ukazano pokrótce główne zasady metafizyczne teilhardyzmu, rolę nauki, filozofii i religii, a także cel historii. Dokonując uważnego przeglądu literatury przedmiotu, autor kwalifikuje poglądy metafizyczne Teilharda jako ewolucyjny panteizm o inspiracji chrześcijańskiej. Zauważa też, że francuski jezuita ulega mirażom pojednania skrajnych wizji filozoficznych i projektów politycznych, co sprawia, że mamy w jego przypadku do czynienia z pełną optymizmu utopią.

Stanowisko Teilharda wobec zagadnienia celu historii jest tego dobitnym przykładem. Jego „uniwersalne państwo” rządzone jest kolektywnie przez „elitę uczonych, łączącą profesorów fizyki, urzędników ONZ i biskupów Kościoła katolickiego. Stolicą świata staje się w tej wizji synteza laickiego Nowego Jorku, marksistowskiej Moskwy i katolickiego Rzymu. Papież jest symbolem tej jedności jako zastępca Chrystusa motoru ewolucji zbieżnej" (s. 254-255). Przykład ostatnich dziesięcioleci świadczy o tym, że sama historia najlepiej weryfikuje tego typu globalne projekty i marzenia. Jak pisze autor w konkluzji, „pomijanie zła moralnego, jednostronne wartościowanie ludzkich dążeń, kolektywizm i uniformizm dają asumpt do zaliczenia Teilhardowskiej wizji dziejów do kategorii utopii, których tak wiele zna historia" (s. 256).

Rafał Łętocha w artykule Mit i religia. Chrześcijańskie i "pogańskie" korzenie idei Legionu św. Michała Archanioła zabiera czytelnika do Rumunii lat dwudziestych ubiegłego wieku z jej "epifenomenem kosmicznego chrześcijaństwa", charakterystycznym - zdaniem Mircei Eliadego dla pasterskich i rolniczych kultur Dacji (s. 257-272). Oparty na nich

30 Tłumaczenie na podstawie włoskiego wydania dzieła H. de Lubaca - zob. H. de Lubac, La posterità spirituale di Gioacchino da Fiore, t. 1: Dagli Spirituali a Schelling, przeł. F. Ciaccia, G. Cattaneo, Jaca Book, Milano 1981, s. 84. 
etos członków Legionu św. Michała Archanioła, powołanego do życia w 1927 roku i biorącego m.in. udział w wojnie domowej w Hiszpanii, był przepojony ideą ofiarnicza, w myśl której bez spokojnie przyjętej śmierci żywej istoty nie może przetrwać żadne dzieło materialne czy duchowe (s. 268). Obok tych elementów tanatycznych w ideologii Legionu znaleźć można kult przodków i ziemi, a także rozwinięte wątki inicjacyjne, przygotowujące jego członków do podejmowania cierpień, w nadziei na powszechną odnowę całego świata.

W dziale Archiwum filozofii polskiej wątki mesjanistyczne znaleźć można w artykule Krzysztofa Tyszki pt. Tadeusz hrabia Dzieduszycki technomesjanista (s. 273-276), a także w tekście tego ostatniego, Generale Warszawy - burza cywilizacji zadaniem na dziś, wydanym w 1948 roku w Londynie (s. 277-284). Tadeusz hrabia Dzieduszycki, urodzony w 1896 roku we Lwowie, prowadził refleksję nad odzyskaną po latach zaborów niepodległością oraz unowocześnieniem kraju. Pragnienia te miały za podstawę przekonanie, że w dziejach świata Polska ma do wypełnienia właściwą jej misję, od której nie może się uchylić. Wyznacznikami tej misji są chrześcijaństwo oraz idea jagiellońska, której wskrzeszenie postuluje Dzieduszycki. Tak sformułowany program przekłada się w jego twórczości na szereg postulatów pod adresem rodaków, podejmujących niełatwą powojenną rzeczywistość, a także na gwałtowne diatryby hrabiego piętnujące inercję i małostkowość liderów:

naszej niezniszczalności i feniksowych wzlotów, nie rozumieją Hachy i Benesze, Mikołajczyki i Koty zaustriaczałe, sławni obrońcy Singapur[u] i lotni dyplomaci Jałty. A mimo to istniejemy i istnieć będziemy - by resztę ludzkości ożywiać, humanizować, holować wzwyż. Takim jest zwycięskie Credo istotnych żołnierzy S p raw y - w Warszawie, na Monte i w Londynie (s. 284).

Wyrazy uznania należą się Redakcji „Kronosa” za podjęcie trudnego wyzwania, jakim jest dzisiaj problem mesjanizmu, oraz prezentacje niezwykle bogatego materiału historycznego i pojęciowego. Problem źródeł mesjanizmu w europejskiej kulturze daleki jest od definitywnego zamknięcia i ciągle toczy się dyskusja na ten temat, stąd pomysł zapoznania polskiego czytelnika z dorobkiem Joachima z Fiore za sprawą tłumaczenia fragmentów jego dzieł i poświęcone mu rozprawy należy uznać za niezwykle cenny i w pełni odpowiadający misji naszej rodzimej nauki. 